\title{
The Role Of Integration Between Lean Construction Tools In Rationalizing Construction Project Costs
}

\author{
Enas Saad Abdal Aziz ${ }^{1}$, Fayhaa abdullah yaqoob ${ }^{2}$ \\ ${ }^{1}$ Financial and Commercial Department, Ministry of Construction, Housing and Public Municipalities, Baghdad, Iraq. \\ ${ }^{2}$ Deanship of the Institute, Baghdad University Higher Institute of Accounting and Financial Studies, Baghdad, Iraq. \\ *Correspondence to : Enas saad abd alaziz ,
}

Assistant account manager,E-mail: enasajili198@gmail.com

\begin{abstract}
:
The construction industries are distinguished from other industries by a special character in terms of their large size and continuous growth, and the dependence of many industries on them to secure their needs of various facilities, as the construction industry is an industry that produces its main product, construction. Examples of construction projects are buildings and paving roads. Building bridges, establishing schools, hospitals, etc. Most of the construction projects suffer from exceeding the specified time and the secret cost of the project, for several reasons, including the work environment, the country's conditions, the method of managing the project's cost, the techniques used in the implementation of the project, and accordingly, the concepts of Lean Manufacturing that help in addressing the causes of waste, in terms of Time and cost, accordingly, this study came to address deviations in the cost or time spent on lean construction techniques and to identify their causes in order to rationalize costs. . In addition to diagnosing waste areas and finding solutions in possible ways through the use of lean construction tools represented in the value flow map, standard work, continuous improvement, and total quality management. To analyze the stages and tasks of any project to reach the sources of waste and try to cancel unnecessary activities and find possible ways to implement them in order to improve the construction work and complete the projects on time and within the planned cost limits, taking into account the maintenance and raising the level of quality.

Keywords: Lean Construction, Standard Work, Continuous Improvement, Total Quality Management.
\end{abstract}

\section{Research problem:}

The research problem is that most construction projects suffer from not implementing them within the specified budget for them, and this results from many reasons that differ according to the different implementation environment Among these reasons, projects exceed the planned time, which leads to incurring the costs of sudden or forced interruptions or the project incurring additional costs that are not matched by a benefit or value added to the project.

\section{The objective of the research:}

The research seeks to achieve the goals of lean construction and the benefits that can be achieved in the event that construction contracting companies adopt this concept, and the following objectives are:
1- Determine the activities that do not add value to the project and thus cause waste of time and try to reduce or eliminate it.

2- Identify deviations in costs and develop possible solutions to rationalize or eliminate them.

3- Defining the impact of integration between lean construction techniques if applied in the field of construction projects.

\section{The importance of the research:}

The importance of research is crystallized in the implementation and management of construction projects according to the techniques of lean construction and the attempt to provide possible solutions and proposals that would reduce waste and loss in future projects and the adoption of modern technologies in project management and the employment of these concepts in the Iraqi 
environment because of their importance in advancing economic development.

\section{Research hypothesis:}

The research starts from a main hypothesis that (the application of integration between Lean construction tools leads to rationalization of construction project costs).

\section{The theoretical side}

1- Project: The project is defined as a unique process, consisting of a set of coordinated and monitored activities with start and end dates, executed to achieve goals that correspond to specific requirements, including time, cost and resource constraints (Lester, 2014: 1). A project is a temporary effort carried out to create a product, service, or unique outcome and this unique product, service, or result is implemented to achieve the goals through the production of a deliverable product (PMBOK GUIDE, 2017: 4). As for the construction project, it is considered one of the complex projects and needs a lot of time. It usually consists of several stages that require a variety of specialized services, starting from the initial planning to the completion of the project as the project passes through successive and distinct phases that require input from different fields Such as financial organizations, government agencies, engineers, architects, attorneys, insurance companies, insurance companies, contractors, materials and equipment manufacturers, suppliers, and workers during the construction processes themselves. Even if the project is of modest or poor proportions, it includes many skills, materials, and hundreds of different processes. The compilation process must follow a natural order of events that form a complex pattern of individual time requirements and restrictive chain relationships between the project's many sectors. (Sears S. Keoki, 2015: 3) Among the most important qualities and objectives that must be achieved to enable the project to achieve the usual standards of success are completion on time, keeping project costs within budget, and meeting the performance and quality requirements stipulated in the specifications. (Lester, 2014: 37).

2- Lean construction: The last few decades have witnessed three major phases or transformations typical of industrial production in the modern world. These stages generally include craft production, mass production and lean production. New concepts such as mass production and lean production reflect ways of thinking about production within specific cultures and eras instead of merely focusing on production systems. Moreover, these production models can be easily linked to the automobile manufacturers of Toyota and Ford, where they are created, practiced, and ultimately evaluated to advanced stages (Gao \& Low, 2014: 27) As the application of lean concepts evolved from the automotive industry, the lean experience was transferred to other manufacturing industries, where lean has been experienced in the construction industry for nearly 20 years (LINDHOLM, 2014: 10). Since 1993 AD the ideas of Lean Production have been introduced into construction, which led to the creation of Lean Construction (Bhosale \& Salunke: 2015,353). Lean construction is defined as a method of designing production systems to reduce the waste of materials, time, efforts in order to maximize value (Gao \& Low, 2014: 36). Lean construction is also defined as a concept that must be introduced in the construction industry, to increase the level of productivity of the sector by eliminating activities and 
procedures that are perceived to generate waste of resources in the construction process (Ingle \& Waghmare, 2015: 19).

3- Principles of Lean construction: The principles of lean construction are divided into five principles, namely: Determining the value is defining the operations of the work site, as what is perceived as value from the customer's point of view, One can suggest that improvements in the traditional construction process are related to this principle. Value flow chart The management of physical flows of people, materials and equipment at construction sites should be taken as part of the production planning and control process. Creating a flow Establishing a continuous flow on construction sites is a major challenge due to its fragmented nature, low standardization patterns of activities, which is one of the unique features of construction products. Creating clouds The principle of clouds and flow is one of the basic characteristics of thinking about lean production, and it is the cornerstone for eliminating waste The benefits of the experience of applying this principle in the field of construction are smaller temporary stores, early project completion and increased productivity. If implemented properly, JIT is also encouraged on building applications by implementing better management practices to eliminate uncertainty and the causes of flow variation. Demanding perfection At this stage, continuous progress can be seen in adopting quality systems programs in implementing construction projects as the results of this strategy are that reasonable improvements and standardization of tasks have been achieved. Lean thinking adopts a broader concept of standard work, Which works to stabilize the operations by accurately determining: the sequence, the method of implementation, and the allowed stock It is important to note that Lean thinking focuses on continuous learning and direct improvements based on the career hierarchy, in a scientific and thoughtful manner. Adopting this strategy also ensures that problems can be detected efficiently and resolved quickly. Therefore, one can point out that even in successful cases of implementing quality programs, additional elements based on simple concepts are necessary, so an environment of improvement and continuous learning is achieved (2-5 Picchi \& Granja, 2004 :). Perfection may not be possible in a building environment, but it is a desirable future condition as defects will be minimized, as is the case with other waste categories that delay delivery, incur additional costs, and detract from meeting customers' needs (Forbes \& Ahmed, 2010: 63).

4- Lean construction tools: The implementation of lean construction tools is the next logical step of cost control methods such as the ABC costing, work packages and the earned value model (Holm, 2018: 131). Lean construction techniques can be defined as a group of processes that aim to eliminate waste in construction and still meet or exceed the expectations of the project owner. The practical techniques used in lean construction can be classified through three levels, which are as follows (Awad Ibrahim, 2016: 35):-

i. The first level: the direct application of the techniques of Lean Manufacturing.

ii. The second level: modification of techniques taken from lean manufacturing.

iii. The third level: the total change to create new lean construction techniques that are completely changed to suit the nature of the construction work. 
Therefore, it can be said that Lean construction does not easily adapt to Lean technology directly from manufacturing to construction. Instead, lean construction tools have been developed in proportion to the nature of work in them (Holm, 2018: 132), and among the tools that have been chosen to apply the research topic are as follows: -

a) the map of the value stream. The value is defined as whatever the customer wants to pay a certain amount in order to obtain it, whether it is material or information (Rahayu, 2009: 116). As for the flow of value, it is defined as a group of activities, whether adding or not adding value to the product, which transforms the product from being understood to launch and from being a mere request to delivery and from raw material to a complete product (Barbara, 2011: 22). A value flow map is also defined as the process that helps managers understand how value is added to the flow of materials and information through the production process as a whole (Heizer et al., 2017: 290). The value flow map is formed through five basic steps which are product family identification, current mapping, analysis and evaluation, future mapping, planning and implementation (Apel, et al. 2007: 11) (Keyte \& Locher, 2016: 7).

b) Standard work, It is the preparation and creation of uniform conditions for work and the standardization of tools, equipment, procedures, materials and other work needs, achieved through standard work consistency in the performance of tasks and implementation of activities and processes (Alston, 2017: 15). Standard work is defined as documenting current knowledge to accomplish all tasks or steps of operations in the best way and with the highest efficiency, in an easier and safer way. It also enables organizations to determine the time required to complete operations and work with the most reliable and accurate estimation of human resources and equipment in order to meet and satisfy customer requirements (SQT, 2015) : 221).

c) Continuous improvement, It is an active strategy that is used to continuously improve processes, procedures, and techniques using input from employees and all levels of the company, and uses a team approach and integrating talent within the company to facilitate improvements (Alston, 2017: 13).

d) Quality Management, It refers to the search for quality within the organization as there are three main philosophies in this approach. The first is a never-ending boost to improvement known as continuous improvement; The second is the participation of everyone in the organization; The third goal is to satisfy the customer, That is, meeting or exceeding customer expectations. Total Quality Management expands the traditional view of quality - looking only at the quality of the final product or services - to consider the quality of every aspect of the process that produces the product or service. Total Quality Management Systems aim to prevent poor quality from occurring (Stevenson, 2018: 390).

\section{The practical side}

\section{1- Define the product family}

Determining the product family in the construction projects sector differs from the one chosen in the other industries sector. The reason is 
that construction projects result in multiple and atypical products in addition to the uniqueness of each product that differs from other products. , As the construction companies implement what the employer requires and according to the specifications and conditions in the contract concluded between the two parties, Accordingly, the product family is selected for identical projects and in construction work, the square meter is the final product, which goes through several stages in order to be completed. In this research, a project was chosen to build a government college to be the family of the producer, and a task was chosen from the project for civil works in the finalization phase to implement the value flow map.

\section{2- Current value flow chart}

Drawing a map of value flow in construction projects is a complex matter because the difference between construction projects and other industries is due to the enormity of details, activities and paragraphs for implementation and completion of projects Therefore, in order to implement the value flow map, the project is divided into stages and stages into civil, electrical, mechanical and sanitary works, and these works are also divided into sub-paragraphs according to the work progress program that is prepared to implement what is mentioned in the bill of quantities, if the value flow map includes details and information It should be clarified as follows: -
A- Information flow: The flow of information begins upon the commencement of the project implementation to complete the paragraphs mentioned in the schedule of quantities and according to the dates specified in the work progress program.

B- Material flow: The flow of materials is of two types, either ready-made materials from the local markets that are purchased under special committees for project procurement, or materials present in the company's warehouses, which are flowed by submitting an order in the required quantity and obtaining approvals in order to prepare a warehouse disbursement document in the specified quantity and transfer it to The project Location.

C- Net available time: The company operates according to the official working hours of government departments, represented by the time between (3-8), equivalent to 420 minutes per day, and an hour of rest is allocated, so the Net Available Time $=\mathbf{4 2 0}-\mathbf{6 0}=\mathbf{3 6 0}$ minutes per day

The researcher chose the section casting and preparing a concrete cast from the civil works detailed in Table (1):

Table (1) Description of the civil works task as it appeared in the bill of quantities

\begin{tabular}{|l|l|c|c|c|}
\hline \multicolumn{1}{|c|}{ Details } & Unit & Total & $\begin{array}{c}\text { Price for } \\
\text { Individual }\end{array}$ & Quantity \\
\hline $\begin{array}{l}\text { Preparing materials and equipment } \\
\text { and casting reinforced concrete }\end{array}$ & M. Square & 44000000 & 40000 & 1100 \\
$\begin{array}{l}\text { with a layer of BRC for floors with } \\
\text { a thickness of 15 cm by using salt- } \\
\text { resistant cement including the } \\
\text { price. }\end{array}$ & & & & \\
\hline
\end{tabular}


Table (2) the stages of implementing the clause of preparing the concrete cast for civil works

\begin{tabular}{|c|c|c|c|c|c|c|c|c|c|c|c|c|c|}
\hline $\begin{array}{c}\begin{array}{c}\text { Total } \\
\text { quantity } \\
\text { used }\end{array} \\
(11) *(2) \\
(12)\end{array}$ & $\begin{array}{c}\text { The } \\
\text { amount } \\
\text { of } \\
\text { materials } \\
\text { per } \\
\text { meter } \\
\\
\text { (11) }\end{array}$ & Materials & $\begin{array}{l}\text { The } \\
\text { number of } \\
\text { mechanisms } \\
\text { for the } \\
\text { required } \\
\text { period } \\
(8) *(3) \\
\text { (9) }\end{array}$ & $\begin{array}{l}\text { Number of } \\
\text { mechanisms }\end{array}$ & Mechanisms & $\begin{array}{c}\text { The } \\
\text { number } \\
\text { of } \\
\text { workers } \\
\text { for the } \\
\text { required } \\
\text { period } \\
(5) *(3) \\
(6)\end{array}$ & $\begin{array}{c}\text { The } \\
\text { number } \\
\text { of labor } \\
\text { per day }\end{array}$ & (4) & $\begin{array}{c}\text { Required } \\
\text { duration } \\
\text { a work ) } \\
1 \text { (day }\end{array}$ & Area & (1) & $\begin{array}{c}\text { The stages } \\
\text { of carrying } \\
\text { out the } \\
\text { task }\end{array}$ & $ت$ \\
\hline- & - & - & 10 & 1 & Car carrying & 10 & 1 & Worker & 10 & 165 & ${ }^{3} \mathrm{~m}$ & Excavations & 1 \\
\hline- & - & - & 3 & 1 & $\begin{array}{c}\text { Ground } \\
\text { leveling } \\
\text { vehicle }\end{array}$ & 3 & 1 & Worker & 3 & 1100 & ${ }^{2} \mathrm{~m}$ & $\begin{array}{r}\text { Good limit } \\
\text { for } \\
\text { earthworks }\end{array}$ & 2 \\
\hline- & - & - & - & - & - & - & - & Worker & 10 & - & - & $\begin{array}{r}\text { Laboratory } \\
\text { testing }\end{array}$ & 3 \\
\hline${ }^{3} \mathrm{~m} 165$ & ${ }^{3} \mathrm{~m} 1$ & Sub-base & 8 & 1 & Car carrying & 32 & 4 & Worker & 8 & 165 & ${ }^{3} \mathrm{~m}$ & $\begin{array}{r}\text { Sub-base } \\
\text { brushes }\end{array}$ & 4 \\
\hline- & - & - & 14 & 1 & $\begin{array}{l}\text { Ground } \\
\text { leveling } \\
\text { vehicle }\end{array}$ & 42 & 3 & Worker & 14 & 1100 & ${ }^{2} \mathrm{~m}$ & $\begin{array}{r}\text { Sub-base } \\
\text { settlement }\end{array}$ & 5 \\
\hline- & - & - & - & - & - & - & - & Worker & 10 & 1100 & ${ }^{2} \mathrm{~m}$ & $\begin{array}{r}\text { Laboratory } \\
\text { testing } \\
\end{array}$ & 6 \\
\hline $\begin{array}{c}{ }^{2} \mathrm{~m} 1100 \\
{ }_{2} \mathrm{~m} 1100 \\
\text { Cans } 5\end{array}$ & $\begin{array}{c}{ }^{2} \mathrm{~m} 1 \\
{ }^{2} \mathrm{~m} 1 \\
\text { Number }\end{array}$ & $\begin{array}{l}\text { Insulation } \\
\text { BRC } \\
\text { Chlorodine }\end{array}$ & - & - & - & 10 & 5 & Worker & 2 & 1100 & ${ }^{2} \mathrm{~m}$ & $\begin{array}{r}\text { Insulation } \\
\text { class } \\
\text { brushes, } \\
\text { BRC, } \\
\text { Chlorodine }\end{array}$ & 7 \\
\hline $\begin{array}{c}\mathrm{Kg} 49.5 \\
{ }^{3} \mathrm{~m} \backslash \\
74.25 \\
132 \\
{ }^{2} \mathrm{~m} 300\end{array}$ & $\begin{array}{c}\mathrm{Kg} 0.3 \\
\mathrm{Kg} 0.45 \\
\mathrm{Kg} 0.8 \\
{ }^{3} \mathrm{~m} 0.27\end{array}$ & $\begin{array}{l}\text { Cemented } \\
\text { sand } \\
\text { Pebble } \\
\quad \text { Wood }\end{array}$ & - & - & - & $\begin{array}{c}3 \\
30\end{array}$ & $\begin{array}{c}1 \\
10\end{array}$ & $\begin{array}{c}\text { Carpenter } \\
\text { Worker }\end{array}$ & 3 & 165 & ${ }^{3} \mathrm{~m}$ & $\begin{array}{r}\text { Concrete } \\
\text { casting }\end{array}$ & 8 \\
\hline
\end{tabular}

What is meant by a working day are the actual days of work without holidays, holidays and any other occasion ${ }^{1}$ 


\begin{tabular}{|c|c|c|c|c|c|c|c|c|c|c|c|c|c|}
\hline $\begin{array}{c}\text { Total } \\
\text { quantity } \\
\text { used }\end{array}$ & $\begin{array}{c}\text { The } \\
\text { amount } \\
\text { of } \\
\text { materials } \\
\text { per } \\
\text { meter } \\
\\
\text { (11) }\end{array}$ & $\begin{array}{c}\text { Materials } \\
\text { (10) }\end{array}$ & $\begin{array}{c}\text { The } \\
\text { number of } \\
\text { mechanisms } \\
\text { for the } \\
\text { required } \\
\text { period } \\
(8)^{*}(3) \\
\text { (9) }\end{array}$ & $\begin{array}{l}\text { Number of } \\
\text { mechanisms }\end{array}$ & Mechanisms & 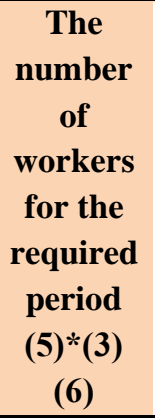 & $\begin{array}{c}\text { The } \\
\text { number } \\
\text { of labor } \\
\text { per day }\end{array}$ & $\begin{array}{l}\text { Workers } \\
\text { Type }\end{array}$ & $\begin{array}{c}\text { Required } \\
\text { duration } \\
\text { a work ) } \\
{ }^{1} \text { (day }\end{array}$ & Area & Unit & $\begin{array}{c}\text { The stages } \\
\text { of carrying } \\
\text { out the } \\
\text { task }\end{array}$ & 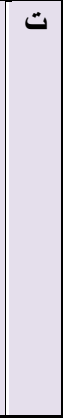 \\
\hline \multirow[t]{2}{*}{-} & - & - & - & - & - & - & - & - & 30 & 12 & cubic & $\begin{array}{r}\text { Laboratory } \\
\text { testing of } \\
\text { concrete } \\
\text { cubes }\end{array}$ & 9 \\
\hline & & & & & & & & & 90 & \multicolumn{3}{|c|}{$\begin{array}{l}\text { Total implementation } \\
\text { (day)period }\end{array}$} & \\
\hline
\end{tabular}

Table (3) costs of the present value flow chart (preparing concrete formwork) for civil works

\begin{tabular}{|c|c|c|c|c|c|c|c|c|c|c|c|c|c|c|}
\hline \multirow[b]{2}{*}{$\begin{array}{l}\text { The total } \\
\text { cost of the } \\
\text { activity } \\
(12)+(8)+(4)\end{array}$} & \multicolumn{4}{|c|}{ Materials } & \multicolumn{4}{|c|}{ Mechanisms } & \multicolumn{4}{|c|}{ Workers } & \multirow[b]{2}{*}{$\begin{array}{c}\text { The stages } \\
\text { of carrying } \\
\text { out the } \\
\text { task } \\
\text { Excavations }\end{array}$} & \\
\hline & $\begin{array}{c}\text { Total } \\
\text { prices of } \\
\text { materials } \\
\text { used } \\
(11) *(10) \\
(12)\end{array}$ & $\begin{array}{c}\text { Individual } \\
\text { material } \\
\text { prices } \\
\\
\text { (11) }\end{array}$ & $\begin{array}{c}\text { The } \\
\text { quantity } \\
\text { required } \\
\text { for the } \\
\text { total } \\
\text { area } \\
\text { (10) }\end{array}$ & Materials & $\begin{array}{c}\text { The } \\
\text { total fee } \\
\text { of the } \\
\text { machine } \\
(7) *(6) \\
(8)\end{array}$ & $\begin{array}{c}\text { Mechanism } \\
\text { wages for } \\
\text { one day }\end{array}$ & $\begin{array}{c}\text { The } \\
\text { number of } \\
\text { mechanisms } \\
\text { for the } \\
\text { required } \\
\text { period } \\
(6)\end{array}$ & $\begin{array}{l}\text { Type and } \\
\text { number of } \\
\text { mechanisms }\end{array}$ & $\begin{array}{c}\text { Total } \\
\text { labor } \\
\text { wages } \\
(3) *(2) \\
\text { (4) }\end{array}$ & $\begin{array}{r}\text { The } \\
\text { amount } \\
\text { of the } \\
\text { worker's } \\
\text { wage } \\
\text { per day } \\
\text { (3) }\end{array}$ & $\begin{array}{c}\text { The } \\
\text { number } \\
\text { of } \\
\text { workers } \\
\text { for the } \\
\text { required } \\
\text { period } \\
\text { (2) }\end{array}$ & $\begin{array}{c}\text { Workers } \\
\text { Type }\end{array}$ & & \\
\hline 2250000 & - & - & - & - & 2000000 & 200000 & 10 & Car carrying & 250000 & 25000 & 10 & Worker & $\begin{array}{r}\text { Good limit } \\
\text { for } \\
\text { earthworks }\end{array}$ & 1 \\
\hline 525000 & - & - & - & - & 450000 & 150000 & 3 & $\begin{array}{l}\text { Ground } \\
\text { leveling }\end{array}$ & 75000 & 25000 & 3 & Worker & $\begin{array}{r}\text { Laboratory } \\
\text { testing }\end{array}$ & 2 \\
\hline
\end{tabular}




\begin{tabular}{|c|c|c|c|c|c|c|c|c|c|c|c|c|c|c|}
\hline The total & & Mat & rials & & & $\mathbf{M e}$ & hanisms & & & Wo & kers & & The stages & \\
\hline $\begin{array}{r}\text { cost of the } \\
\text { activity } \\
(12)+(8)+(4) \\
\text { (13) }\end{array}$ & $\begin{array}{c}\begin{array}{c}\text { Total } \\
\text { prices of }\end{array} \\
\text { materials } \\
\text { used }\end{array}$ & $\begin{array}{c}\text { Individual } \\
\text { material } \\
\text { prices }\end{array}$ & $\begin{array}{c}\text { The } \\
\text { quantity } \\
\text { required } \\
\text { for the } \\
\text { total } \\
\text { area } \\
\text { (10) }\end{array}$ & (9) & $\begin{array}{c}\begin{array}{c}\text { The } \\
\text { total fee } \\
\text { of the } \\
\text { machine }\end{array} \\
(7)^{*}(6) \\
(8)\end{array}$ & $\begin{array}{c}\text { Mechanism } \\
\text { wages for } \\
\text { one day } \\
\text { (7) }\end{array}$ & $\begin{array}{c}\text { The } \\
\text { number of } \\
\text { mechanisms } \\
\text { for the } \\
\text { required } \\
\text { period } \\
\text { (6) }\end{array}$ & $\begin{array}{l}\text { Type and } \\
\text { number of } \\
\text { mechanisms } \\
\text { (5) }\end{array}$ & $\begin{array}{c}\text { Total } \\
\text { labor } \\
\text { wages } \\
(3)^{*}(2) \\
\\
\text { (4) }\end{array}$ & $\begin{array}{r}\text { The } \\
\text { amount } \\
\text { of the } \\
\text { worker's } \\
\text { wage } \\
\text { per day } \\
\text { (3) }\end{array}$ & $\begin{array}{l}\text { The } \\
\text { number } \\
\text { of } \\
\text { workers } \\
\text { for the } \\
\text { required } \\
\text { period } \\
\text { (2) }\end{array}$ & $\begin{array}{c}\text { Workers } \\
\text { Type }\end{array}$ & $\begin{array}{c}\text { of carrying } \\
\text { out the } \\
\text { task } \\
\text { Excavations }\end{array}$ & \\
\hline & & & & & & & & vehicle & & & & & & \\
\hline 90000 & - & - & - & - & - & - & - & - & - & - & - & Worker & $\begin{array}{r}\text { Sub-base } \\
\text { brushes }\end{array}$ & 3 \\
\hline 6030000 & 3630000 & 22000 & ${ }^{3} \mathrm{~m} 165$ & Sub-base & 1600000 & 200000 & 8 & Car carrying & 800000 & 25000 & 32 & Worker & $\begin{array}{r}\text { Sub-base } \\
\text { settlement }\end{array}$ & 4 \\
\hline 3150000 & - & - & - & - & 2100000 & 150000 & 14 & $\begin{array}{l}\text { Ground } \\
\text { leveling } \\
\text { vehicle }\end{array}$ & 1050000 & 25000 & 42 & Worker & $\begin{array}{r}\text { Laboratory } \\
\text { testing }\end{array}$ & 5 \\
\hline 90000 & - & - & - & - & - & & - & - & - & - & - & Worker & $\begin{array}{r}\text { Insulation } \\
\text { class } \\
\text { brushes, } \\
\text { BRC, } \\
\text { Chlorodine }\end{array}$ & 6 \\
\hline 8575000 & $\begin{array}{c}3850000 \\
4400000 \\
75000\end{array}$ & $\begin{array}{r}{ }^{2} \mathrm{~m} 3500 \\
{ }^{2} \mathrm{~m} 4000 \\
15000 \\
\text { Each) } \\
\text { (Cans }\end{array}$ & $\begin{array}{r}\mathrm{m} 21100 \\
\mathrm{~m} 21100 \\
\text { Cans } 5\end{array}$ & $\begin{array}{l}\text { Insulation } \\
\text { BRC } \\
\text { Chlorodine }\end{array}$ & - & - & - & - & 250000 & 25000 & 10 & Worker & $\begin{array}{r}\text { Concrete } \\
\text { casting }\end{array}$ & 7 \\
\hline 18733750 & $\begin{array}{l}6435000 \\
\\
2598750 \\
6600000 \\
3000000 \\
\end{array}$ & $\begin{array}{l}130000 \\
\\
35000 \\
50000 \\
10000\end{array}$ & $\begin{array}{r}\mathrm{Kg} \quad 49.5 \\
\text { Im3 } \\
74.25 \\
132 \\
\mathrm{~m}^{2} 300\end{array}$ & $\begin{array}{r}\text { Cemented } \\
\text { sand } \\
\text { Pebble } \\
\text { Wood }\end{array}$ & - & - & - & - & $\begin{array}{l}225000 \\
750000\end{array}$ & $\begin{array}{l}75000 \\
25000\end{array}$ & $\begin{array}{l}3 \\
30\end{array}$ & $\begin{array}{l}\text { Carpenter } \\
\text { Worker }\end{array}$ & $\begin{array}{r}\text { Laboratory } \\
\text { testing of } \\
\text { concrete } \\
\text { cubes }\end{array}$ & 8 \\
\hline 192000 & 192000 & 16000 & cube12 & - & - & - & - & - & - & - & - & - & $\begin{array}{l}\text { The stages } \\
\text { of carrying }\end{array}$ & 9 \\
\hline
\end{tabular}




\begin{tabular}{|c|c|c|c|c|c|c|c|c|c|c|c|c|c|}
\hline & \multicolumn{4}{|c|}{ Materials } & \multicolumn{4}{|c|}{ Mechanisms } & \multicolumn{4}{|c|}{ Workers } & \multirow{2}{*}{$\begin{array}{c}\text { The stages } \\
\text { of carrying } \\
\text { out the } \\
\text { task } \\
\text { Excavations }\end{array}$} \\
\hline $\begin{array}{c}(12)+(8)+(4) \\
(13)\end{array}$ & $\begin{array}{c}\begin{array}{c}\text { Total } \\
\text { prices of } \\
\text { materials } \\
\text { used }\end{array} \\
(11) *(10) \\
(12)\end{array}$ & $\begin{array}{c}\begin{array}{c}\text { Individual } \\
\text { material } \\
\text { prices }\end{array} \\
\text { (11) }\end{array}$ & $\begin{array}{c}\text { The } \\
\text { quantity } \\
\text { required } \\
\text { for the } \\
\text { total } \\
\text { area } \\
\\
(10)\end{array}$ & Materials & $\begin{array}{c}\begin{array}{c}\text { The } \\
\text { total fee } \\
\text { of the } \\
\text { machine }\end{array} \\
(7) *(6) \\
(8)\end{array}$ & $\begin{array}{c}\text { Mechanism } \\
\text { wages for } \\
\text { one day } \\
\text { (7) }\end{array}$ & $\begin{array}{c}\text { The } \\
\text { number of } \\
\text { mechanisms } \\
\text { for the } \\
\text { required } \\
\text { period } \\
\text { (6) }\end{array}$ & $\begin{array}{l}\text { Type and } \\
\text { number of } \\
\text { mechanisms }\end{array}$ & $\begin{array}{c}\text { Total } \\
\text { labor } \\
\text { wages } \\
(3)^{*}(2) \\
\\
(4)\end{array}$ & $\begin{array}{r}\text { The } \\
\text { amount } \\
\text { of the } \\
\text { worker's } \\
\text { wage } \\
\text { per day } \\
\text { (3) }\end{array}$ & $\begin{array}{c}\text { The } \\
\text { number } \\
\text { of } \\
\text { workers } \\
\text { for the } \\
\text { required } \\
\text { period } \\
\text { (2) }\end{array}$ & $\begin{array}{c}\text { Workers } \\
\text { Type }\end{array}$ & \\
\hline & & & & & & & & & & & & & $\begin{array}{c}\text { out the } \\
\text { task }\end{array}$ \\
\hline 39635750 & $\mathbf{3 0 7 8 0 7 5 0}$ & & & & 6150000 & & & & 3400000 & & & The to & al cost of the \\
\hline 36032.5 & & & & & & & & & & & & ${ }^{2}$ The cost & er square m \\
\hline
\end{tabular}

The cost per square meter is extracted by dividing the total cost of the paragraph, which is 39635750 dinars $/ 1100 \mathrm{~m} 2^{2}$ 
From Table (3) the time period for each stage of the implementation of the concrete formwork provision for civil works was calculated as the implementation is calculated as an actual working day, as the actual working days were converted into hours based on the daily working hours, which are (7) hours per hour) 8) in the morning until (3) in the afternoon, and during the day there is one hour for the worker to rest at (12) in the afternoon, Therefore, the rest hour was excluded as it does not add value to the work, and the waiting period before starting any stage also does not add value to the work, as in the waiting time that exists before starting each test phase, as it is exhausted in official approvals and the routine of government departments and sampling, so the rest time and waiting time A time that adds no value to work.

For each stage of the implementation of the clause of preparing the concrete formwork, the target productivity rate and the time of recurrence or completion called Takt time will be calculated from the following equations: -

\section{i. $\quad$ Target Tpr. = Space Required $/$ Time Spent \\ ii. frequency time $\mathrm{Tt}$. = Daily available working time / Targeted productivity rate}

Now we can draw the current map as in Figure (1):

Figure (1) Present Value Flow Map - Civil Works

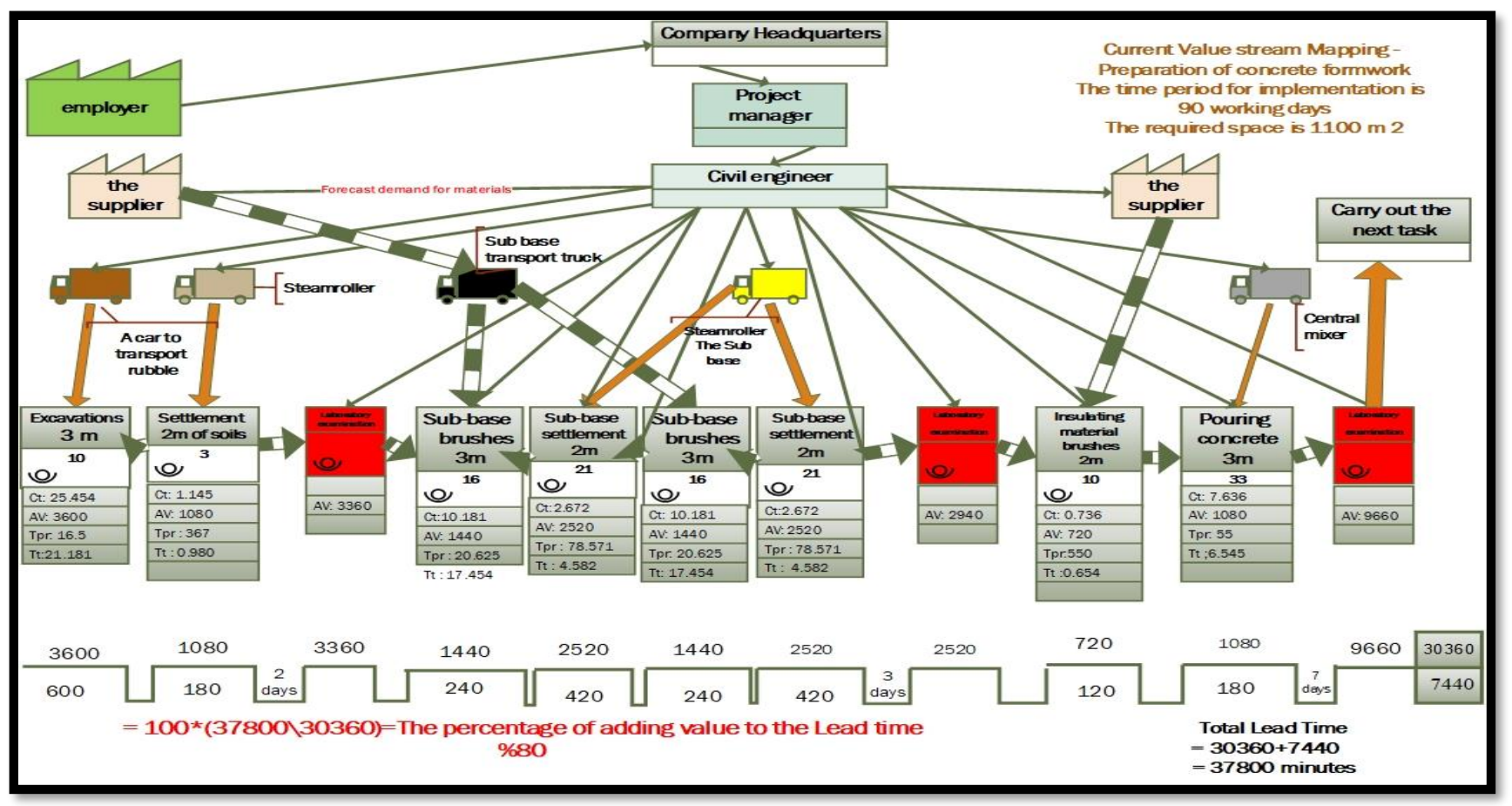

Source: Researcher setup based on Visio Professional

\section{3- Present value flow chart analysis}

After collecting data and organizing them into tables and stages, calculating costs, then calculating the information for the data box and drawing the current map of the value flow And it became possible to notice defects and waste in costs or time, as well as discovering places for improvement to improve the construction work and generalize the proposed ideas on a larger scale for implementation through the implementation of future projects, The construction works of all kinds need to apply some lean construction tools in order to reduce the waste in cost and time and raise the efficiency of the completed works. 
Among these tools is the standard work SW By comparing the current implementation of the works with the standard guide for price analysis of the construction sector for civil works in its first part for the year 2013, we note that the standard works are calculated taking into account the actual working hours 8 hours / day (Standard Guide, 2013: 7), Accordingly, 8 working hours per day will be adopted at the rate of one hour of rest for all work and subsequent paragraphs in order to improve productivity and raise efficiency. After describing the current map for the section of preparing the concrete cast from the civil works, it is possible to include what has been observed in terms of defects and areas of improvement as follows: -

a) The paragraph does not include weekly reports on the reality of work and any suggestions and ideas that serve the quality of implementation and raise the efficiency of workers.

b) The paragraph exceeds the target cost planned for the completion of the project, which is $80 \%$ of the contract price and because the prices of the paragraphs specified in the schedule of quantities are fixed and cannot be changed Therefore, there is no way to reduce costs in order to implement the chosen paragraph except to control the number of workers to reduce the wages paid and control the number of days of implementation for the same previous goal.

c) The implementation period was 115 days and the number of actual working days was 90 days. This means a deviation from the time specified for implementation by 16 days because the planned working days for implementation are 99 days, which led to the increase in implementation days and incurred additional burdens and costs.

d) By comparing the current productivity rates with the productivity rates in the standard guide, the following is revealed as in Table (4): -

Table (4) Productivity rates for drilling, brushing and border work

\begin{tabular}{|l|c|c|c|}
\hline \multicolumn{1}{|c|}{ Details } & $\begin{array}{c}\text { The number } \\
\text { of Worker }\end{array}$ & $\begin{array}{c}\text { Number and } \\
\text { type of } \\
\text { mechanisms }\end{array}$ & $\begin{array}{c}\text { Productivity } \\
\text { / day }\end{array}$ \\
\hline $\begin{array}{l}\text { Dirt excavation works at } \\
\text { different depths / m3 }\end{array}$ & 2 & $\begin{array}{c}\text { Car carrying } \\
1\end{array}$ & $3 \mathrm{~m} 150$ \\
\hline $\begin{array}{l}\text { Brushing works for } \\
\text { crushed gravel }\end{array}$ & 2 & $\begin{array}{c}\text { Car carrying } \\
1\end{array}$ & $2 \mathrm{~m} 200$ \\
\hline $\begin{array}{l}\text { Corruption work for } \\
\text { gallstones }\end{array}$ & $\begin{array}{c}\text { Ground } \\
\text { leveling } \\
\text { lvehicle }\end{array}$ & $2 \mathrm{~m} 200$ \\
\hline
\end{tabular}

\section{Source: Preparing the researcher based on the standard guide for construction works}

By comparing productivity rates between the current implementation and the standard evidence, it was revealed that there is a difference that affects the number of days of completion and the project carries additional costs and wasted time.
1. By comparing the amount of wood used with the standard quantity in the standard guide in the molding activity, we note that the used quantity is (300) $\mathrm{m} 2$ to pour the required area, which is (165) $\mathrm{m} 3$, while the standard quantity in the guide is $(0.21) \mathrm{m} 2$ per square meter of concrete Includes waste 
(Standard Guide, 2013: 52), so the standard quantity that is supposed to be used is $(0.21$ * 1100 square meters) and equals 231 square meters, which means that there is a waste in the amount of wood used.

2. The activities related to laboratory tests require a waiting period before each activity, due to the routine, official books, and sampling until the actual examination begins, while this waste of time can be avoided through the overlap between activity times, which contributes to reducing the time lost in waiting before Initiate laboratory testing activity.

3. Some activities are carried out routinely, as in the activities of brushes and settlement for Al-Sub-base, where these activities are carried out in two stages for each of them and separately, which takes time to implement the required space while it is possible to merge some of them.
4. Increasing the productivity of the worker through the standard work SW, which would determine the tasks required for each worker and the state before starting the implementation of task in order to reduce the time not to add value to the work performed In addition to the application of TQM, which contributes to documenting the business in the form of written procedures that facilitate its application by workers, in addition to achieving the expectations of the customer and achieving his needs and reaching the goals of the company in the most efficient and least expensive way by exploiting the energy of workers with continuous motives for development. In Table (5) a summary of the proposed improvements to the section of preparing the concrete casts: -

Table (5) improvements in the concrete formwork preparation section

\begin{tabular}{|l|l|c|c|}
\hline \multicolumn{1}{|c|}{ Details } & $\begin{array}{c}\text { Current } \\
\text { time } \\
(\text { minutes }\end{array}$ & $\begin{array}{c}\text { New time } \\
\text { (minutes) }\end{array}$ \\
\hline 1 & Waiting period before the laboratory test activity & 840 & 0 \\
\hline & $\begin{array}{l}\text { Laboratory examination after soil reduction } \\
\text { Laboratory examination after setting SPACE } \\
\text { second stage }\end{array}$ & 1260 & 0 \\
\hline 2 & $\begin{array}{l}\text { Laboratory examination after the molding stage } \\
\text { she two activities combining a good mapping } \\
\text { area with the brushes of the space for the first stage } \\
\text { of the remaining space }\end{array}$ & 2940 & 0 \\
\hline
\end{tabular}

\section{4- Drawing the proposed map}

Through the stage of analysis and suggesting improvements, We can draw the proposed map after calculating the measures of the proposed value flow map, The standard 8-hour actual working hours as mentioned in the standard guide were relied upon, So the available working time is
(1-8) and equals $(7 * 60)$, so that the net available time after excluding the rest time equals 420 minutes per day. The productivity rates mentioned in the standard guide of the Ministry of Construction and Housing have also been relied on . And now the proposed map can be drawn as in the figure(2):- 
Figure (2) a proposed value stream map for civil works

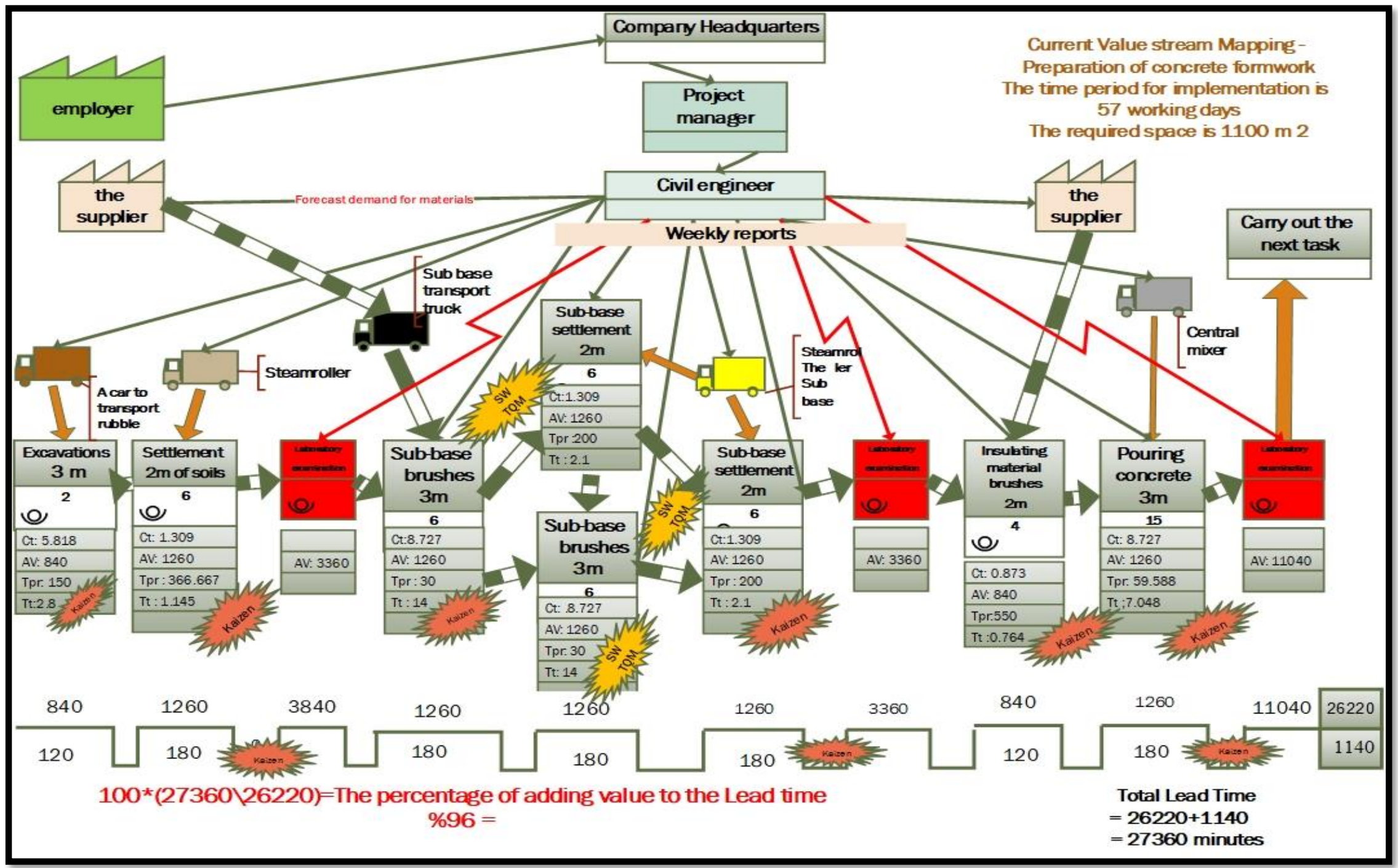

Source: Researcher setup based on 2016 Visio Professional $\backslash$ Office application 
Table (6) costs of the proposed value flow map (preparing concrete casts) for civil works

\begin{tabular}{|c|c|c|c|c|c|c|c|c|c|c|c|c|c|c|c|c|}
\hline \multirow{2}{*}{$\begin{array}{c}\text { Total } \\
\text { activity } \\
\text { cost }\end{array}$} & \multicolumn{4}{|c|}{ Materials } & \multicolumn{4}{|c|}{ Mechanisms } & \multicolumn{6}{|c|}{ Employment } & \multirow[b]{2}{*}{$\begin{array}{c}\text { Activity } \\
\text { name }\end{array}$} & \multirow[t]{2}{*}{$ت$} \\
\hline & $\begin{array}{l}\text { Total } \\
\text { prices of } \\
\text { the } \\
\text { require } \\
\text { d } \\
\text { material } \\
\mathrm{s} \\
\text { 11)*(10) } \\
( \\
\text { (12) }\end{array}$ & $\begin{array}{c}\text { Individu } \\
\text { al } \\
\text { material } \\
\text { prices }\end{array}$ & $\begin{array}{c}\text { The } \\
\text { quantit } \\
y \\
\text { require } \\
\text { d for } \\
\text { the } \\
\text { total } \\
\text { area } \\
\\
\\
\text { (10) }\end{array}$ & Materials & $\begin{array}{c}\text { Total } \\
\text { wages of } \\
\text { the } \\
\text { machine } \\
\text { s } \\
(7)^{*}(6) \\
\text { (8) }\end{array}$ & \begin{tabular}{c}
\multicolumn{2}{c}{ Mechanis } \\
m wages \\
for one \\
day
\end{tabular} & $\begin{array}{c}\text { The } \\
\text { number of } \\
\text { mechanis } \\
\text { ms for the } \\
\text { required } \\
\text { period } \\
\text { (6) }\end{array}$ & $\begin{array}{r}\text { Type of } \\
\text { mechanis } \\
\text { ms }\end{array}$ & $\begin{array}{l}\text { Total } \\
\text { labor } \\
\text { wages } \\
(3) *(2)\end{array}$ & $\begin{array}{c}\text { Averag } \\
\text { e daily } \\
\text { wage }\end{array}$ & $\begin{array}{c}\text { The } \\
\text { number } \\
\text { of } \\
\text { worker } \\
\mathrm{s} \\
\text { require } \\
\text { d for } \\
\text { the } \\
\text { total } \\
\text { period } \\
\\
\text { (2) }\end{array}$ & 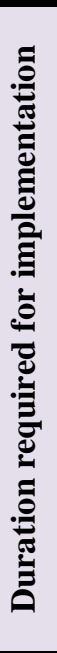 & 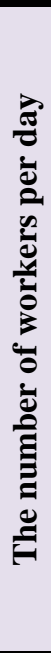 & $\begin{array}{c}\text { Type of } \\
\text { employme } \\
\text { nt }\end{array}$ & & \\
\hline 450000 & - & - & - & - & 400000 & 200000 & 2 & $\begin{array}{c}\text { Car } \\
\text { carrying }\end{array}$ & 50000 & 25000 & 2 & 2 & 1 & Worker & Fossils & 1 \\
\hline \multirow[t]{2}{*}{600000} & - & - & - & - & 450000 & 150000 & 3 & $\begin{array}{l}\text { A car to } \\
\text { level the } \\
\text { ground }\end{array}$ & 150000 & 25000 & 6 & 3 & 2 & Worker & $\begin{array}{l}\text { Good limit } \\
\text { for } \\
\text { earthworks }\end{array}$ & 2 \\
\hline & - & - & - & - & 0 & & - & - & 0 & - & - & 8 & - & - & $\begin{array}{l}\text { Laboratory } \\
\text { examinatio } \\
\mathrm{n}\end{array}$ & 3 \\
\hline 5130000 & 3630000 & 22000 & ${ }^{3}+165$ & سبيس & 1200000 & 200000 & 6 & $\begin{array}{c}\text { Car } \\
\text { carrying }\end{array}$ & 300000 & 25000 & 12 & 6 & 2 & Worker & $\begin{array}{l}\text { Sub-base } \\
\text { brushes in } \\
\text { two stages }\end{array}$ & 4 \\
\hline \multirow[t]{2}{*}{1200000} & - & - & - & - & 900000 & 150000 & 6 & $\begin{array}{l}\text { A car to } \\
\text { level the } \\
\text { ground }\end{array}$ & 300000 & 25000 & 12 & 6 & 2 & Worker & $\begin{array}{l}\text { Leveling } \\
\text { sub-base } \\
\text { after } \\
\text { brushes }\end{array}$ & 5 \\
\hline & - & - & - & - & & & - & - & 0 & - & - & 7 & - & - & $\begin{array}{l}\text { Laboratory } \\
\text { examinatio } \\
\mathrm{n}\end{array}$ & 6 \\
\hline 8425000 & 3850000 & ${ }^{2} \mathrm{~m} 3500$ & ${ }^{2} \mathrm{~m} 1100$ & Insulating & & - & - & - & 100000 & 25000 & 4 & 2 & 2 & Worker & Insulation & 7 \\
\hline
\end{tabular}




\begin{tabular}{|c|c|c|c|c|c|c|c|c|c|c|c|c|c|c|c|c|}
\hline \multirow{2}{*}{$\begin{array}{c}\text { Total } \\
\text { activity } \\
\text { cost }\end{array}$} & \multicolumn{4}{|c|}{ Materials } & \multicolumn{4}{|c|}{ Mechanisms } & \multicolumn{6}{|c|}{ Employment } & \multirow[b]{2}{*}{$\begin{array}{l}\text { Activity } \\
\text { name }\end{array}$} & \multirow[t]{2}{*}{ 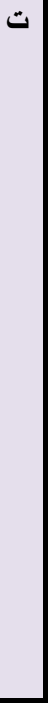 } \\
\hline & $\begin{array}{c}\text { Total } \\
\text { prices of } \\
\text { the } \\
\text { require } \\
\text { d } \\
\text { material } \\
\text { s } \\
\begin{array}{c}11)^{*}(10) \\
( \\
(12)\end{array}\end{array}$ & $\begin{array}{c}\text { Individu } \\
\text { al } \\
\text { material } \\
\text { prices }\end{array}$ & $\begin{array}{c}\text { The } \\
\text { quantit } \\
y \\
\text { require } \\
\text { d for } \\
\text { the } \\
\text { total } \\
\text { area }\end{array}$ & $\begin{array}{c}\text { Materials } \\
\text { (9) }\end{array}$ & $\begin{array}{c}\text { Total } \\
\text { wages of } \\
\text { the } \\
\text { machine } \\
\text { s } \\
(7)^{*}(6) \\
\text { (8) }\end{array}$ & $\begin{array}{l}\text { Mechanis } \\
\text { m wages } \\
\text { for one } \\
\text { day }\end{array}$ & $\begin{array}{l}\text { The } \\
\text { number of } \\
\text { mechanis } \\
\text { ms for the } \\
\text { required } \\
\text { period } \\
\text { (6) }\end{array}$ & $\begin{array}{r}\text { Type of } \\
\text { mechanis } \\
\text { ms }\end{array}$ & $\begin{array}{c}\text { Total } \\
\text { labor } \\
\text { wages } \\
(3)^{*}(2) \\
\\
(4)\end{array}$ & $\begin{array}{c}\text { Averag } \\
\text { e daily } \\
\text { wage }\end{array}$ & $\begin{array}{c}\text { The } \\
\text { number } \\
\text { of } \\
\text { worker } \\
\text { s } \\
\text { require } \\
\text { d for } \\
\text { the } \\
\text { total } \\
\text { period } \\
\text { (2) }\end{array}$ & 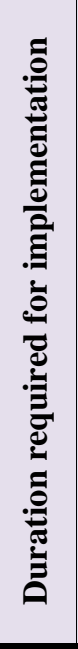 & 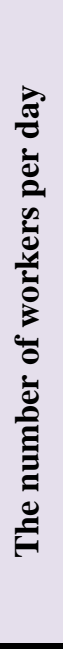 & $\begin{array}{c}\text { Type of } \\
\text { employme } \\
\text { nt }\end{array}$ & & \\
\hline & $\begin{array}{c}4400000 \\
75000\end{array}$ & $\begin{array}{l}{ }^{2} \mathrm{~m} 4000 \\
15000 \\
\text { Each ) } \\
\text { (packet }\end{array}$ & $\begin{array}{l}{ }^{2} \mathrm{~m} 1100 \\
\text { Cans } 5\end{array}$ & $\begin{array}{l}\text { material } \\
\text { BRC } \\
\text { A packet } \\
\text { of } \\
\text { chlorodine }\end{array}$ & & & & & & & & & & & $\begin{array}{l}\text { brushes, } \\
\text { BRC, } \\
\text { Chlorodine }\end{array}$ & \\
\hline $\begin{array}{c}1846875 \\
0\end{array}$ & $\begin{array}{l}6435000 \\
2598750 \\
6600000 \\
2310000\end{array}$ & $\begin{array}{l}130000 \\
35000 \\
50000 \\
10000\end{array}$ & $\begin{array}{c}\mathrm{Kg} 49.5 \\
{ }^{3} \mathrm{~m} \backslash \\
74.25 \\
132 \\
{ }^{2} \mathrm{~m} 231\end{array}$ & $\begin{array}{l}\text { Cement } 1 \\
\text { ton } \\
\text { Sand } 1 \mathrm{~m} 3 \\
\text { Cobbleston } \\
\text { e } 1 \mathrm{~m} 3 \\
\quad \quad \text { Wood }\end{array}$ & & - & - & - & $\begin{array}{l}225000 \\
300000\end{array}$ & 25000 & 12 & 3 & 4 & $\begin{array}{l}\text { Carpenter } \\
\text { Worker }\end{array}$ & $\begin{array}{l}\text { Casting } \\
\text { thickness } \\
(15) \mathrm{cm} \\
\text { casting in } \\
\text { three } \\
\text { stages }\end{array}$ & 8 \\
\hline 192000 & 192000 & 16000 & cubic12 & - & & - & - & - & $\mathbf{0}$ & - & & 23 & & - & $\begin{array}{l}\text { Laboratory } \\
\text { testing of } \\
\text { concrete } \\
\text { cubes }\end{array}$ & 9 \\
\hline $\begin{array}{c}3446575 \\
0\end{array}$ & $\begin{array}{c}3009075 \\
0\end{array}$ & & & & 2950000 & & & & $\begin{array}{c}142500 \\
0\end{array}$ & & & & & $\begin{array}{r}\text { The to } \\
=\text { The cost }\end{array}$ & $\begin{array}{l}\text { I cost of the } j \\
r \text { square me }\end{array}$ & \\
\hline
\end{tabular}




\begin{tabular}{|c|c|c|c|c|c|c|c|c|c|c|c|c|c|c|c|c|}
\hline \multirow{2}{*}{$\begin{array}{c}\text { Total } \\
\text { activity } \\
\text { cost }\end{array}$} & \multicolumn{4}{|c|}{ Materials } & \multicolumn{4}{|c|}{ Mechanisms } & \multicolumn{6}{|c|}{ Employment } & \multirow[b]{2}{*}{$\begin{array}{c}\text { Activity } \\
\text { name }\end{array}$} & \multirow[t]{2}{*}{ ت } \\
\hline & $\begin{array}{c}\text { Total } \\
\text { prices of } \\
\text { the } \\
\text { require } \\
\text { d } \\
\text { material } \\
\text { s } \\
11)^{*}(10) \\
( \\
\text { (12) }\end{array}$ & $\begin{array}{c}\text { Individu } \\
\text { al } \\
\text { material } \\
\text { prices }\end{array}$ & $\begin{array}{l}\text { The } \\
\text { quantit } \\
\text { y } \\
\text { require } \\
\text { d for } \\
\text { the } \\
\text { total } \\
\text { area }\end{array}$ & Materials & $\begin{array}{c}\text { Total } \\
\text { wages of } \\
\text { the } \\
\text { machine } \\
\text { s } \\
(7)^{*}(6) \\
\text { (8) }\end{array}$ & \begin{tabular}{rr}
\multicolumn{2}{c}{ Mechanis } \\
m wages \\
for $\begin{array}{r}\text { one } \\
\text { day }\end{array}$
\end{tabular} & $\begin{array}{l}\text { The } \\
\text { number of } \\
\text { mechanis } \\
\text { ms for the } \\
\text { required } \\
\text { period } \\
\text { (6) }\end{array}$ & $\begin{array}{r}\text { Type of } \\
\text { mechanis } \\
\text { ms }\end{array}$ & $\begin{array}{l}\text { Total } \\
\text { labor } \\
\text { wages } \\
(3)^{*}(2)\end{array}$ & $\begin{array}{c}\text { Averag } \\
\text { e daily } \\
\text { wage }\end{array}$ & $\begin{array}{c}\text { The } \\
\text { number } \\
\text { of } \\
\text { worker } \\
\mathbf{s} \\
\text { require } \\
\text { d for } \\
\text { the } \\
\text { total } \\
\text { period } \\
\text { (2) }\end{array}$ & 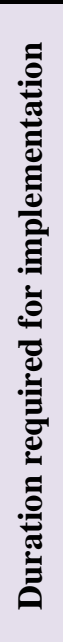 & 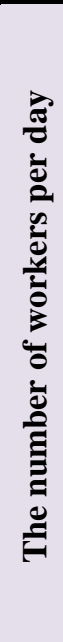 & $\begin{array}{c}\text { Type of } \\
\text { employme } \\
\text { nt }\end{array}$ & & \\
\hline 31332.5 & & & & & & & & & & & & & & & & \\
\hline
\end{tabular}

Table (7) a comparison between the results and measures of the current and proposed map of the value flow for the concrete formwork preparation

\begin{tabular}{|c|c|c|c|c|c|c|c|c|c|c|c|c|c|c|c|}
\hline Details & $\begin{array}{l}\text { Cycle } \\
\text {.time Ct } \\
\text { Minute) } \\
\quad( \\
\text { Propose } \\
\quad \text { d }\end{array}$ & $\begin{array}{c}\text { Cycle } \\
\text {.time Ct }\end{array}$ & 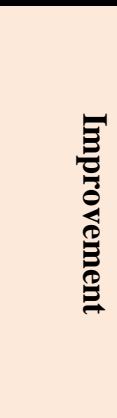 & $\begin{array}{c}\text { Time } \\
\text { not to } \\
\text { add } \\
\text { value } \\
\text { Propose } \\
\quad \text { d }\end{array}$ & $\begin{array}{c}\text { Time } \\
\text { not to } \\
\text { add } \\
\text { value } \\
\text { Present }\end{array}$ & 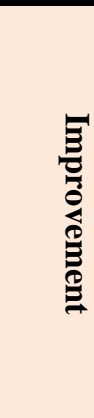 & $\begin{array}{l}\text { Time to } \\
\text { add } \\
\text { value } \\
\text { Propose } \\
\text { d }\end{array}$ & $\begin{array}{c}\text { Time to } \\
\text { add } \\
\text { value }\end{array}$ & 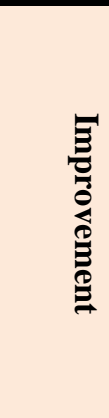 & $\begin{array}{l}\text { Takt } \\
\text { time } \\
\\
\text { Propose } \\
\quad \text { d }\end{array}$ & $\begin{array}{l}\text { Takt } \\
\text { time }\end{array}$ & 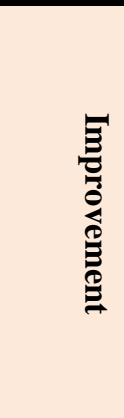 & $\begin{array}{c}\text { Targete } \\
\text { d } \\
\text { product } \\
\text { ivity } \\
\text { rate } \\
\\
\text { propose } \\
\text { d }\end{array}$ & $\begin{array}{c}\text { Targete } \\
\text { d } \\
\text { product } \\
\text { ivity } \\
\text { rate } \\
\\
\text { Present }\end{array}$ & 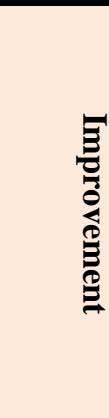 \\
\hline Excavations & 5.818 & 25.454 & 19.636 & 120 & 600 & 480 & 840 & 3600 & 2760 & 2.8 & 21.181 & 18.381 & 150 & 16.5 & 133.5 \\
\hline $\begin{array}{l}\text { Good limit for } \\
\text { earthworks }\end{array}$ & 1.309 & 1.145 & -0.164 & 180 & 180 & 0 & 1260 & 1080 & -180 & 1.145 & 0.98 & -0.165 & 366.667 & 367 & -0.333 \\
\hline Laboratory testing & - & - & - & 480 & 840 & 360 & 3360 & 3360 & 0 & - & - & - & - & - & - \\
\hline $\begin{array}{l}\text { Sub-base brushes in } \\
\text { two stages } 7.5 \mathrm{~cm}\end{array}$ & 8.727 & 10.181 & 1.454 & 180 & 240 & 60 & 1260 & 1440 & 180 & 14 & 17.454 & 3.454 & 30 & 20.625 & 9.375 \\
\hline
\end{tabular}




\begin{tabular}{|c|c|c|c|c|c|c|c|c|c|c|c|c|c|c|c|}
\hline $\begin{array}{l}\text { Leveling sub-base } \\
\text { after brushes }\end{array}$ & 1.309 & 2.672 & 1.363 & 180 & 420 & 240 & 1260 & 2520 & 1260 & 2.1 & 4.582 & 2.482 & 200 & 78.571 & 121.429 \\
\hline $\begin{array}{l}\text { Sub-base brushes in } \\
\text { two stages } 7.5 \mathrm{~cm}\end{array}$ & 8.727 & 10.181 & 1.454 & 180 & 240 & 60 & 1260 & 1440 & 180 & 14 & 17.545 & 3.545 & 30 & 20.625 & 9.375 \\
\hline $\begin{array}{l}\text { Leveling sub-base } \\
\text { after brushes }\end{array}$ & 1.309 & 2.672 & 1.363 & 180 & 420 & 240 & 1260 & 2520 & 1260 & 2.1 & 4.582 & 2.482 & 200 & 78.571 & 121.429 \\
\hline Laboratory testing & - & - & - & 420 & 1260 & 840 & 2940 & 2940 & 0 & - & - & - & - & - & - \\
\hline $\begin{array}{l}\text { Insulation brushes, } \\
\text { BRC, Chlorodine }\end{array}$ & 0.873 & 0.763 & -0.11 & 120 & 120 & 0 & 840 & 720 & -120 & 0.764 & 0.654 & -0.11 & 550 & 550 & 0 \\
\hline $\begin{array}{l}\text { Casting thickness } \\
\text { (15) cm casting in } \\
\text { three stages }\end{array}$ & 8.727 & 7.636 & -1.091 & 180 & 180 & 0 & 1260 & 1080 & -180 & 7.048 & 6.545 & -0.503 & 59.588 & 55 & 4.588 \\
\hline $\begin{array}{l}\text { Laboratory testing } \\
\text { of concrete cubes }\end{array}$ & - & - & - & 1380 & 2940 & 1560 & 9660 & 9660 & 0 & - & & - & - & - & - \\
\hline
\end{tabular}




\section{5- Implementation of the action plan}

From table (6) we note that the total cost of the task after implementing the proposals has reached (34465750) dinars, which is equivalent to (31332.5) dinars per square meter. This cost meets the goal to reach the target cost, and even less than it. In addition to the implementation period, as the working days were reduced from 90 to 57 working days after implementing the improvements. In Table (8) we notice the most important changes if the proposed map were adopted:

\section{Table (8): Changes in the results of the current and proposed value flow chart for the section of preparing the concrete casts}

\begin{tabular}{|c|c|c|c|}
\hline Details & $\begin{array}{c}\text { Suggested } \\
\text { results }\end{array}$ & $\begin{array}{c}\text { Current } \\
\text { results }\end{array}$ & $\begin{array}{c}\text { Planned } \\
\text { results }\end{array}$ \\
\hline $\begin{array}{c}\text { Duration of execution } \\
\text { /working days }\end{array}$ & 57 & 90 & 98 \\
\hline The cost per meter & 31332.5 & 36032.5 & 32000 \\
\hline
\end{tabular}

\section{Conclusions:}

We conclude from the previous steps that the application of lean construction techniques contributes to reducing the waste of cost and time by canceling activities that do not add value to the final product and applying the standard guide for construction work, which contributes to reducing the waste in cost, whether in the wages of direct labor or the mechanisms used or materials Used during the implementation phases in addition to the implementation period, Therefore, the standard work is integrated with the implementation of the value flow map activities in conjunction with the application of total quality management in order to implement the work in a more efficient and effective manner and satisfy the customer's conviction, and certainly permeates these techniques and their application for continuous improvement, which adds progressively improvement to the work performed in order to apply the previous techniques and the integration in what Among them, to rationalize the costs of construction projects.

\section{References}

[1] Lester, Albert, Project Management Planning and Control, Managing
Engineering,

Construction, \& Manufacturing Projects to PMI, APM, and BSI Standards, Oxford, ButterworthHeinemann,6th ed, (2014).

[2] Project Management Institute , PMBOK GUIDE Sixth Edition, A Guide to the PROJECT MANAGEMENT BODY OF KNOWLEDGE ,2017.

[3] Sears, S., Rounds, J. L., Clough, R. H., Sears, G. A., \& Segner, R. O. (2015). Construction project management: a practical guide to field construction management.

[4] Gao, Shang, and Sui Pheng Low. "Lean construction management." The Toyota Way 2014.

[5] LINDHOLM TOMAS, Lean in Construction Projects, Is lean suitable for all construction projects? Master Thesis, Stockholm 2014.

[6] Bhosale, Pooja, and Hemant Salunke. "Value stream mapping: case study on residential construction sector." (2015).

[7] Ingle, Aakanksha, and Ashish P. Waghmare. "Advances in Construction: Lean Construction for Productivity enhancement and waste minimization." 
International Journal of Engineering and Applied Sciences 2.11 (2015).

[8] Picchi, Flavio Augusto, and Ariovaldo Denis Granja. "Construction sites: using lean principles to seek broader implementations." Proceedings of the 12th Annual Conference of the International Group for Lean Construction (IGLC-12), Helsingør, Denmark. 2004.

[9] Forbes, Lincoln H., and Syed M. Ahmed. Modern construction: lean project delivery and integrated practices. CRC press, 2010.

[10] Holm,Len , "Cost Accounting and Financial Management for Construction Project Managers" ,2018,

[11] Awad, Ibrahim Mohammed Omer. (2016) Applying lean construction concepts to construction industry in Sudan. Diss. Sudan University of Science and Technology.

[12] Rahayu, Devi Adhriany. Building Model Of Basic Stability For Productivity Improvement Journey In PT. Dow Agrosciences Indonesia By Utilizing Value Stream Mapping (VSM) In Production Shop Floor. MS thesis. 2009.

[13] Barbara, Santa .(2011).Training Guidelean manufacturing QAD Enterprise Application, Standard\&Enterprise Edition, WWW.qad.com. (Accessed September 30, 2020)

[14] Forbes, Lincoln H., and Syed M. Ahmed. Modern construction: lean project delivery and integrated practices. CRC press, 2010.

[15] Heizer, J., Render, B., \& Munson, C. (2017). Operations Management:
Sustainability and Supply Chain Management (12th Ed). Pearson Education, Inc.

[16] Apel, Wolfgang\&Yongli,Jia and Walton, Vanessa . (2007). value stream mapping for lean manufacturing implementation, Bachelor of Science / university of science \& Technology .

[17] Keyte, B., \& Locher, D. A. (2016). The Complete Lean Enterprise Value Stream Mapping for Office and Services (2nd Ed). CRC Press Taylor \& Francis Group. : Keyte, B., \& Locher, D. A. (2016). The complete lean enterprise: Value stream mapping for administrative and office processes. (2nd Ed), Productivity Press,P:7

[18] Alston, Frances . (2017) , Lean Implementation Applications and Hidden Costs , Taylor \& Francis Group, LLC.

[19] SQT, Lean Manufacturing Tools , SQT Training Ltd, 2015.

[20] Stevenson, W. J. (2018). Operations management. T H I RT E E N T H E D I T I O N, McGraw-hill.

[21] https://www.lucidchart.com/pages/valuestream-mapping/value-stream-mappingsymbols\#section. Accessed(26\1\2021)

[22] Ministry of Construction and Housing, Standard Guide for Price Analysis for the Building and Construction Sector, (2013), Part One, issued by virtue of Royal Decree No. 63 of 2012. Available at the link (https://www.moch.gov.iq/uploads/part.1_ AttachFile41.pdf.)

\section{$\underline{\text { Supplement }}$}

Table (1) the meanings of the process symbols in the value flow map

\begin{tabular}{|c|c|c|c|}
\hline the meaning & Symbol & the meaning & Symbol \\
\hline Data box & $\begin{array}{c}\text { Data } \\
\text { Data } 2 \\
\text { Data } 3\end{array}$ & Customer / Supplier & \\
\hline & & A custom process & 。 \\
\hline
\end{tabular}




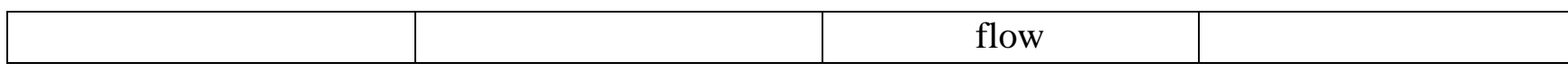

Table (2) the meanings of the material symbols in the Value Stream Map

\begin{tabular}{|c|c|c|c|}
\hline the meaning & Symbol & the meaning & Symbol \\
\hline Pull material & & The store & \\
\hline FIFO line & $\overline{-F I F 0 \rightarrow}$ & Shipping share & 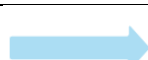 \\
\hline External shipment & - $\bullet$ & Pay share & 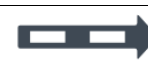 \\
\hline & & Super Market & 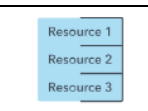 \\
\hline
\end{tabular}

Table (3) the meanings of the information symbols in the value stream map

\begin{tabular}{|c|c|c|c|}
\hline the meaning & Symbol & the meaning & Symbol \\
\hline Pull kanban & & Production control & \\
\hline Kanban reference & & Manual information & \\
\hline Kanban cards site & & $\begin{array}{c}\text { Electronic } \\
\text { information }\end{array}$ \\
\hline
\end{tabular}

Table (4) the meanings of the general symbols in the Value Stream Map

\begin{tabular}{|c|c|c|c|}
\hline the meaning & Symbol & the meaning & Symbol \\
\hline other information & & Kaizen emission & \\
\hline timetable & & $\begin{array}{c}\text { The number of employees or } \\
\text { operators }\end{array}$ \\
\hline
\end{tabular}

